\title{
David Harvey, Rebel Cities: From the Right to the City to the Urban Revolution. (New York: Verso, 2012).
}

David Harvey is one of those rare scholars whose work has transcended the alltoo-rigidly policed academic division of labour. He is the most widely cited academic geographer, ${ }^{1}$ and his online lecture series on Marx's Capital has widened his influence among academics and activists alike. Rebel Cities brings together a number of his most recently published articles, most of them written since the onset of the so-called sub-prime crisis and its transformation into a fully fledged global recession (The sole exception here is the chapter on "The Art of Rent," large portions of which were published in the 2002 Socialist Register - a full halfdecade before the onset of the crisis). The book offers a concise restatement of his long-standing and relatively well-known argument about the 'urban dynamics' of capital accumulation, and the way in which capitalist crises have historically been resolved through the promotion of large-scale infrastructure development and urbanization. In addition, Rebel Cities includes extended discussions around the concept of the 'urban commons,' and whether-or-not "horizontalist" forms of political organization are sufficient in-and-of-themselves to manage these commons (67-89); around the theory of monopoly rent, which Harvey uses to examine what he calls the "Disneyfication" of contemporary urban centres (89115); and around the need for Marxist scholars and activists to recast their definition of the 'revolutionary agent' to include not only the 'conventional' working class, but also the numerous social groups involved in the reproduction of daily life - domestic labourers, city employees, and other workers that do not contribute directly to the process of capitalist value production.

Harvey begins by offering a brief history outlining the connections between capitalist crises and the urbanization process. The main argument here is one that Harvey has developed at length elsewhere: ${ }^{2}$ the masses of surplus value produced in capitalist societies must constantly find profitable outlets for reinvestment, and in times of stagnating or declining profitability, the urban built environment proves to be especially enticing as an 'absorber' of this surplus. The reasons for this are numerous: investment in the construction of housing, office buildings and transportation infrastructures, for instance, all require relatively lengthy 'gestation periods,' such that the issue of profitability can be put off into the relatively distant future. The prospect of appropriating 'already-created' surplus value in the form of regular rental payments, rather than engaging in that 'pesky' process of value production, is likewise a motivating factor, according to Harvey (129). This general dynamic - wherein capital, often at the insistence of an activist state, is channeled into what Harvey calls the 'secondary circuit of capital'-provides the theoretical basis for the author's explanation of the numerous urban transformations that have littered the history of industrial capitalism. Thus, Harvey argues that, in Second Empire France, the crisis of the 
mid-nineteenth century was resolved in large part through Haussmann's restructuring of the Parisian infrastructure and geography; Haussmann "transformed the scale at which the urban process was imagined," Harvey writes (7). Indeed, the wide-avenues and elaborate department stores for which the French capital is well known are a direct product of this period of 'urban restructuring.' The scale at which the urban process is 'imagined' underwent a further transformation in the United States in the aftermath of the Great Depression and the Second World War, with the mass construction of suburban housing, and the far-reaching transformations in daily life and consumer culture that these latter developments entailed (8-10).

But these processes of urban transformation, redemptive as they have been for capital, have nonetheless been accompanied by the destruction of those built-environments in which working and poor people carry out their daily lives. The reconstruction of New York City in the aftermath of the Second World War, for instance, involved Robert Moses, a sort of latter-day Haussmann, "taking a meat axe" to the working class neighbourhoods of that city (17). Similar processes have accompanied the restructuring of cities in the Global South: Harvey notes that during the Seoul property boom of the mid-1990s, "the construction companies and developers hired goon squads of sumo wrestler types to invade whole neighbourhoods and smash down with sledgehammers not only the housing but also all the possessions of those who had built their own housing on the hillsides of the city in the 1950s" (19). Broadly similar processes have been taking place in the United States in the aftermath of the subprime crisis, albeit often shrouded in the seemingly benign legalistic jargon of 'eminent domain.' As Florida Congressman Alan Grayson wrote in a letter to the state's Supreme Court Justice, referring to the wave of foreclosures then sweeping thecountry: " $\mathrm{l} \mathrm{f}$ the reports I am hearing are true, the illegal foreclosures taking place represent the largest seizure of private property ever attempted by banks and government entities" (54).

Although Harvey has made a name for himself theorizing the way in which capital has transformed the urban environment, he devotes a good part of Rebel Cities to thinking through the ways in which a more equitable, non-capitalist social formation might be organized (67-89). Harvey rightly eschews the task of constructing 'blueprints' for such a society, but he does offer a critical and timely intervention around the concept of 'horizontalism,' which has gained traction among leftist scholars and activists in recent years. In doing so, he focuses mainly on the work of Nobel Prize-winner Elinor Ostrom, who argues in her book, Governing the Commons, that locally based and non-hierarchical structures of governance have been historically quite successful in managing the shared resources of small communities. Although Ostrom's work has been especially influential among 'Occupy' activists and other proponents of radically decentralized systems of government, Harvey warns that such solutions are not 
likely workable at the scale of the modern-day metropolis. He writes:

The possibilities for sensible management of common property resources that exist at one scale (such as shared water rights between one hundred farmers in a small river basin), do not and cannot carry over to problems such as global warming, or even to the regional diffusion of acid deposition from power stations (69).

Governance systems based on the ideas of "polycentricity" (82-4) or "confederalism" (152) are unlikely to succeed, Harvey suggests, unless they engage more seriously with this problem of scale.

But while Harvey rightly abstains from mapping out the political structures of a prospective 'socialist' society, he does offer suggestions as to how a broadly-conceived anti-capitalist left might better resist the depredations wrought by the capitalist growth imperative. Harvey's main intervention here is made against those 'orthodox' Marxists, who insist on an overly narrow definition of the 'working class.' Indeed, the history of those 'rebel cities' that have sought to construct alternative modes of working and living-from the sans-culottes of the Paris Commune to those residents of El Alto who fought on the front-lines of Bolivia's 'water wars' (141-50)_shows that the most successful modes of resistance are those founded on broad-based alliances between neighbourhood groups, 'traditional' unions, city workers and service providers, and allied groups of precarious workers, rather than some narrowly-defined 'industrial proletariat' $(132 ; 147-8)$. In more general terms, the 'revolutionary agent' must be recast to include all of those individuals and groups engaged in the urbanization process and the 'reproduction of daily life' - a term Harvey borrows from Lefebvre (139). Although such a conception of the 'revolutionary agent' may seem threatening to those committed to a more 'orthodox' version of Marxism (120), Harvey makes it clear that such a re-conception is not out of keeping with the broader Marxian tradition: the reproduction of capitalism as a mode of production, after all, is dependent not only on value-creating labour carried-out in the factories, (which in any case has been 'radically diminished' in the so-called advanced capitalist counties (130), but on all sorts of labours that are currently 'unproductive' from capital's vantage point -doctors, nurses and other caregivers; teachers and garbage collectors; as well as bus drivers and subway workers, among others. There is much in Rebel Cities that is thought provoking and deserving of careful consideration. As a book though, it holds together sometimes rather tenuously. The connections between the 'structural forces' outlined in the earlier chapters, for instance, and the more agency-focused analysis in the latter part of the book are too often simply implicit in the analysis. The final chapters on the London riots (155-7) and the Occupy Movement (159-64) seem especially disconnected in this respect. Nonetheless, the book deserves a hearty recommendation - especially for professors of urban studies and related disciplines seeking an accessible 'primer' on Harvey's particular brand of urban political economy. 


\section{NOTES}

1 Andrew Bodman, "Weavers of Influence: The Structure of Contemporary Geographic Research," in Transactions of the Institute of British Geographers New Series, Vol. 16 No. 1 (1991): 26.

2 See David Harvey, The Limits to Capital (New York: Verso, 2006 [1981]); The Urbanization of Capital (Baltimore: Johns Hopkins University Press, 1985);

Consciousness and the Urban Experience (Baltimore: Johns Hopkins University Press, 1985); The Enigma of Capital and the Crises of Capitalism (Oxford: Oxford University Press, 2012).

Peter Braun York University

Editors Note: This review edited by Mary Franks 